\title{
THE EFFECTS OF SOOTY MOLD ON PHOTOSYNTHESIS AND MESOPHYLL STRUCTURE OF MAHOGANY (SWIETENIA MACROPHYLLA KING., MELIACEAE) (1)
}

\author{
JOSÉ PIRES DE LEMOS FILHO (2); ÉLDER ANTÔNIO SOUSA PAIVA ${ }^{(2)}$
}

\begin{abstract}
The aim of present study was to evaluate the effects of the sooty mold on anatomy and photochemical activity of mahogany (Swietenia macrophylla) leaves. The photochemical features of shadedeveloped leaves with or without sooty mold were compared to those of sun leaves using chlorophyll $a$ fluorescence measurements. Leaf anatomy was also evaluated using conventional techniques. The degree of blockage of the photosynthetic active photon flux density (PPFD) by sooty mold and its effect on photochemistry were evaluated. Sun leaves showed thick mesophyll with palisade parenchyma disposed in a uniseriate layer, whereas shade leaves showed narrow mesophyll, independently of sooty mold presence. The effective quantum yield $\left(\Delta \mathrm{F} / \mathrm{Fm}^{\prime}\right)$ and the apparent electron transport rate (ETR) of sun leaves were higher than those of shade leaves. The values of ETR suggested that photochemistry saturation occurred at lower PPFD in shade-grown plants. Lower values of the $\Delta \mathrm{F} / \mathrm{Fm}^{\prime}$ and, consequently, lower values of ETR were observed in leaves with sooty mold. A reduction of $40 \%$ of the incident light was seen due to physical blockage by sooty mold which is presumably responsible for an additional decrease of ETR values. Our data indicated that sooty mold did not directly damage the leaf, but reduce leaf photochemistry capacity, by decreasing light availability.
\end{abstract}

Key words: chlorophyll fluorescence, leaf anatomy,photochemical activity.

\section{RESUMO}

\section{EFEITOS DA FUMAGINA SOBRE A FOTOSSÍNTESE E A ESTRUTURA DO MESOFILO DE MOGNO}

O objetivo do presente estudo foi avaliar os efeitos da fumagina na anatomia e a atividade fotoquímica em folhas de mogno (Swietenia macrophylla King., Meliaceae). Folhas com e sem fumagina desenvolvidas na sombra foram comparadas com as de folhas de sol, para verificar as diferenças em parâmetros fotoquímicos utilizando-se medidas de fluorescência. As amostras de folhas destinadas a estudos anatômicos foram processadas segundo técnicas convencionais. A intensidade de bloqueio da radiação densidade de fótons fotossinteticamente ativos (DFFA) pela fumagina e seu efeito sobre a atividade fotoquímica foram avaliados. As folhas de sol têm mesofilo espesso e parênquima paliçádico unisseriado enquanto nas folhas de sombra o mesofilo é delgado, independentemente da presença ou não de fumagina. $\mathrm{O}$ rendimento quântico efetivo $\left(\Delta \mathrm{F} / \mathrm{Fm}^{\prime}\right)$ e a taxa aparente de transporte de elétrons (ETR) das folhas de sol foram superiores às das folhas de sombra. Os valores de ETR sugerem que, nas plantas crescidas na sombra, a saturação da atividade fotoquímica ocorre em menores valores de DFFA. Observaram-se menores valores de $\Delta \mathrm{F} / \mathrm{Fm}$ ' nas folhas com fumagina e, conseqüentemente menores valores de ETR. A presença de fumagina promoveu bloqueio de $40 \%$ na luz incidente e, conseqüentemente, presume-se um decréscimo adicional nos valores de ETR. Pelos dados, verifica-se que a presença de fumagina não promoveu danos diretos nas folhas, mas reduz a capacidade fotoquímica por diminuir a disponibilidade de luz.

Palavras-chave: anatomia foliar, atividade fotoquímica, fluorescência da clorofila.

${ }^{1}$ ) Recebido para publicação em 17 de agosto de 2004 e aceito em 28 de novembro de 2005.

$\left(^{2}\right)$ Departamento de Botânica, Instituto de Ciências Biológicas, Universidade Federal de Minas Gerais, $31270-901$ Belo Horizonte (MG), Brazil. E-mail: epaiva@icb.ufmg.br 


\section{INTRODUCTION}

The growth of fungal mycelium on a leaf surface in a non-parasitic relationship is a common type of epiphytic life. Sooty mold, a capnodiaceous ascomycete, belongs to the Capnodiales, a monophyletic saprophytic group of fungi characterized by folicolous habit and darkly pigmented hyphae that grow on adaxial leaf surface (REYNOLDS, 1998).

The accumulation of fungal mat on the adaxial surface does not cause physical lesion to the leaf, but has the potential to reduce sunlight penetration and suppress photosynthesis (Wood et al., 1988). In pecan leaves, TEDDERS e SMITH (1976) showed that sooty mold reduces light transmission by $25 \%$. The deleterious effect of sooty mold seems to result from leaf shading, through reduction of photosynthetic capacity and premature leaf abscision (SPARKS e YATES, 1991). In an evaluation of the effects of heavy sooty mold on light penetration and photosynthesis of pecan leaves, Wood et al. (1988) observed a 70\% suppression on net photosynthesis due to a blockage of photosynthetically active radiation (PAR).

Many plant species develop anatomically distinct leaves in response to different light availability (Vogelmann e Martin, 1993; StraussDebenedetTi e BerLyn, 1994), which may result in the so-called sun and shade leaves (CUTTER, 1978). In Tradescantia pallida leaves, PAIVA et al. (2003) described high anatomical and physiological plasticity due to light intensity variations. However, studies on the effects of light intensity on mahogany leaf structure are not available in literature.

Swietenia species, especially the Brazilian mahogany (Swietenia macrophylla) is well known for their wood quality (Pennington et al., 1981). It was once a common species of canopy tree in both wet and dry forests of the neotropics but it has been subjected to heavy logging (GERHARD e FREDRIKSSON, 1995) that has brought increased risk of extinction (Barbosa, 1992).

Considering that studies on sooty mold impact on leaf structure and function were basically restricted to agricultural species, in the present study we investigate the effects of sooty mold in Swietenia macrophylla King. (mahogany), an Amazonian tree species, in order to evaluate the effects of sooty mold on leaf photochemistry and structure. The effects of sooty mold on leaf anatomy, light transmission, and photochemical capacity were studied. The features of shade-developed leaves with or without fungal mycelia were compared to those of sun leaves to determine the differences in the photochemical parameters by chlorophyll $a$ fluorescence.

\section{MATERIAL AND METHODS}

Seeds of Swietenia macrophylla were collected from plants growing at the Universidade Federal de Minas Gerais (UFMG) campus, Minas Gerais State, Brazil. After germination, seedlings were transferred to plastic bags containing $3 \mathrm{~kg}$ of loamy soil, and were maintained under shade conditions given by tree canopies. For comparative analysis some seedlings were maintained in full sunlight conditions. For eight months, the seedlings were regularly supplied with water and $100 \mathrm{~mL}$ of half-strength Hoagland solution. During the wet season, intense and spontaneous development of sooty mold on leaf surfaces was observed. At this time, leaflets were collected for anatomical studies, and photosynthetic and light transmission measurements were performed.

For anatomical studies, samples from the central portion of mature leaflets were taken in shade (with and without sooty mold) and full-sunlightexposed seedlings. Fresh hand-cut sections were obtained, double-stained with safranin-astrablue (BuKATsCH, 1972), and photographed on an Olympus $\mathrm{BH}-2$ light microscope. Leaves of sun seedlings were fixed in FAA 50 (JOHANSEN, 1940), embedded in glycolmethacrylate, sectioned $(10 \mathrm{~mm})$ in a rotatory microtome, and stained with Toluidin Blue (O'BRIEN et al., 1964).

Measurements of chlorophyll $a$ fluorescence were performed using a portable chlorophyll fluorometer (Walz) on one leaflet per seedling. Light response curves were obtained using the light curve program of the instrument. Actinic light on leaves was increased up to ca. $2.500 \mu \mathrm{mol} . \mathrm{m}^{-2} \cdot \mathrm{s}^{-1}$ during 4 minutes in 8 steps of 30 seconds each. At each level of light supplied by the instrument, a saturation pulse was applied and chlorophyll fluorescence parameters recorded. The effective quantum yield was given as $\Delta \mathrm{F} / \mathrm{Fm}^{\prime}=\left(\mathrm{Fm}^{\prime}-\mathrm{F}\right) / \mathrm{Fm}^{\prime}$, where $\mathrm{F}$ is the steady-state chlorophyll fluorescence yield of light-adapted leaves and $\mathrm{Fm}^{\prime}$ the maximum chlorophyll fluorescence caused by the saturation pulse. The apparent electron transport rate was performed according to KRALL e EDWARDS (1992), ETR $=\left(\Delta \mathrm{F} / \mathrm{Fm}^{\prime}\right) \mathrm{x} . \mathrm{PPFD} \times 0.5 \times 0.84$, where 0.5 was used as the fraction of excitation energy distributed to PSII, PPFD the incident photosynthetic photon flux, and 0.84 was used as the fractional light absorbance (SCHREIBER et al. 1995). As pointed out by 
LutTGE et al. (1998), due to the short time of light exposure at each step during the measurements, the correct absolute values of ETR were not obtained, but comparative assessments of the performance of leaves within a short time interval are possible in this way.

The degree of photosynthetically active radiation (PAR) blockage by sooty mold was evaluated in four seedlings by measuring light transmission through leaflets. Leaflets with sooty mold were collected and immediately submitted to different incident photosynthetic photon flux densities (PPFD) supplied by a halogen lamp (light source model $2050 \mathrm{H}, \mathrm{Walz})$. The incident and transmitted light through the leaflet blade were measured using a LI190 quantum sensor (Li-Cor). Fungal mycelium was removed with humid wool and light transmission was measured again, in the same leaflets.

\section{RESULTS AND DISCUSSION}

Seedlings of $S$. macrophylla growing in shade conditions showed sooty mold hyphae distributed on the leaf adaxial surface. These hyphae enter neither the epidermal nor the mesophyll cells (Figure 1A). Sooty mold was observed only in fresh hand-cut preparations, once they were removed from the leaf surface by the other techniques used for anatomical studies.

Sun leaves showed thicker mesophyll (ca. 600 $\mathrm{mm}$ ) with larger uniseriate palisade cells than shade leaves (Figure 1B). Shade leaves, with and without sooty mold, showed similar height, but narrower uniseriate palisade parenchyma in relation to sun ones (Figure 1A and C). In the present study, a strong structural difference between sun and shade leaves was evident. On the other hand, no anatomical differences were observed between shade leaves with and without sooty mold. The effects of light intensity variation on leaf anatomical structure may be intense only if leaves are exposed to different light levels during the differentiation phase (CUTTER, 1978; PAIVA et al., 2003). As spontaneous development of the sooty mold occurred just after leaves had reached their final structure, the reduction of transmitted light caused by sooty mold did not affect leaf structure.

The effective quantum yield $\left(\Delta \mathrm{F} / \mathrm{Fm}^{\prime}\right)$ and consequently the apparent electron transport rate (ETR) of sun leaves (Figure 2) were higher than that of shade leaves (Figure 3), independently of the sooty mold presence. It was observed that the saturation of the ETR of shade leaves occurred at a lower level of PPFD (ca. 500 umol. $\mathrm{m}^{-2} \mathrm{~s}^{-1}$ ), when compared to sun

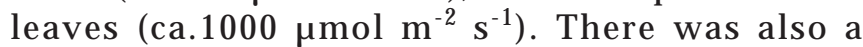

significant difference between values of the $\Delta \mathrm{F} / \mathrm{Fm}^{\prime}$ of leaves with or without sooty mold (Figure $3 \mathrm{~A}$ ). At around $300 \mu \mathrm{mol} . \mathrm{m}^{-2} \mathrm{~s}^{-1}$ of PPFD the values of $\Delta \mathrm{F} /$ $\mathrm{Fm}^{\prime}$ were lower in leaves with sooty mold in relation to healthy ones, respectively $0.112 \pm 0.02$ and $0.194 \pm$ $0.01(t=7.260, p=0.0003)$. As consequence of the lower $\Delta \mathrm{F} / \mathrm{Fm}^{\prime}$ values, leaves with sooty mold showed also lower values of ETR with the maximum values of 28.4 $\pm 1.1 \mu \mathrm{mol} . \mathrm{m}^{-2} \mathrm{~s}^{-1}$ in healthy leaflets and $15.5 \pm 2.7$ $\mu \mathrm{mol} \cdot \mathrm{m}^{-2} \mathrm{~s}^{-1}$ in leaflets with sooty mold (Figure 3B).

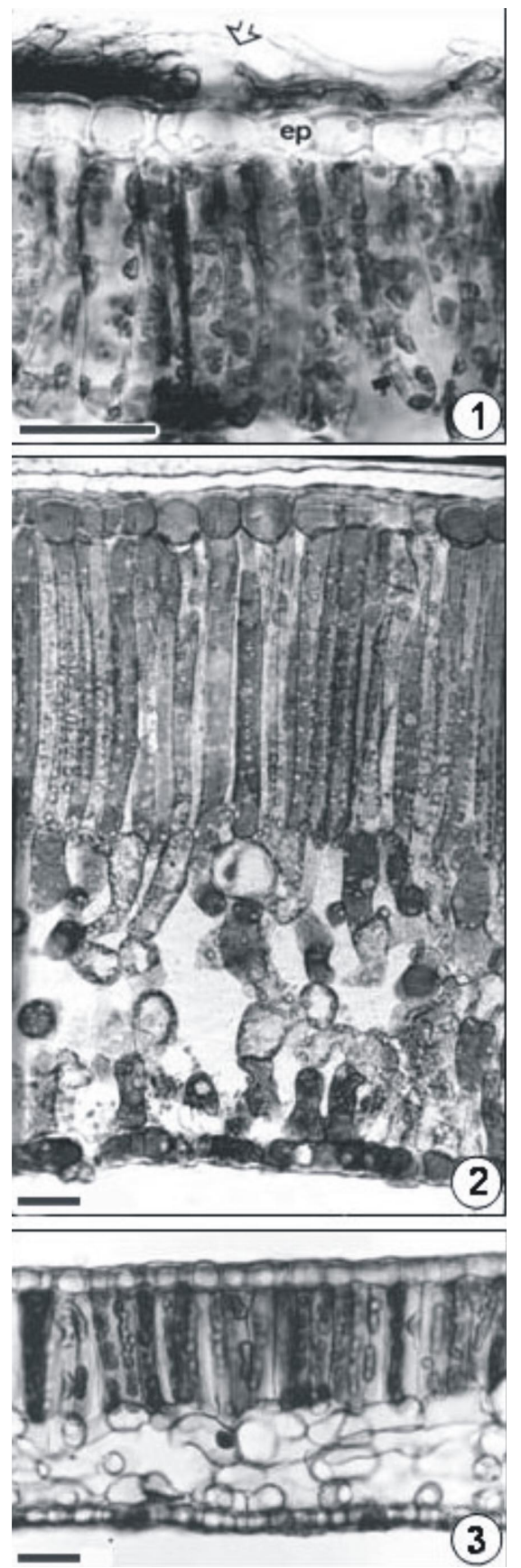

Figure 1. Transverse sections of $S$. macrophylla leaf. 1) detail of shade leaf with sooty mold. Arrow indicate hyphal presence on adaxial surface. 2) sun leaf without sooty mold. 3) shade leaf without sooty mold. (bar $=25 \mu \mathrm{m})$. 

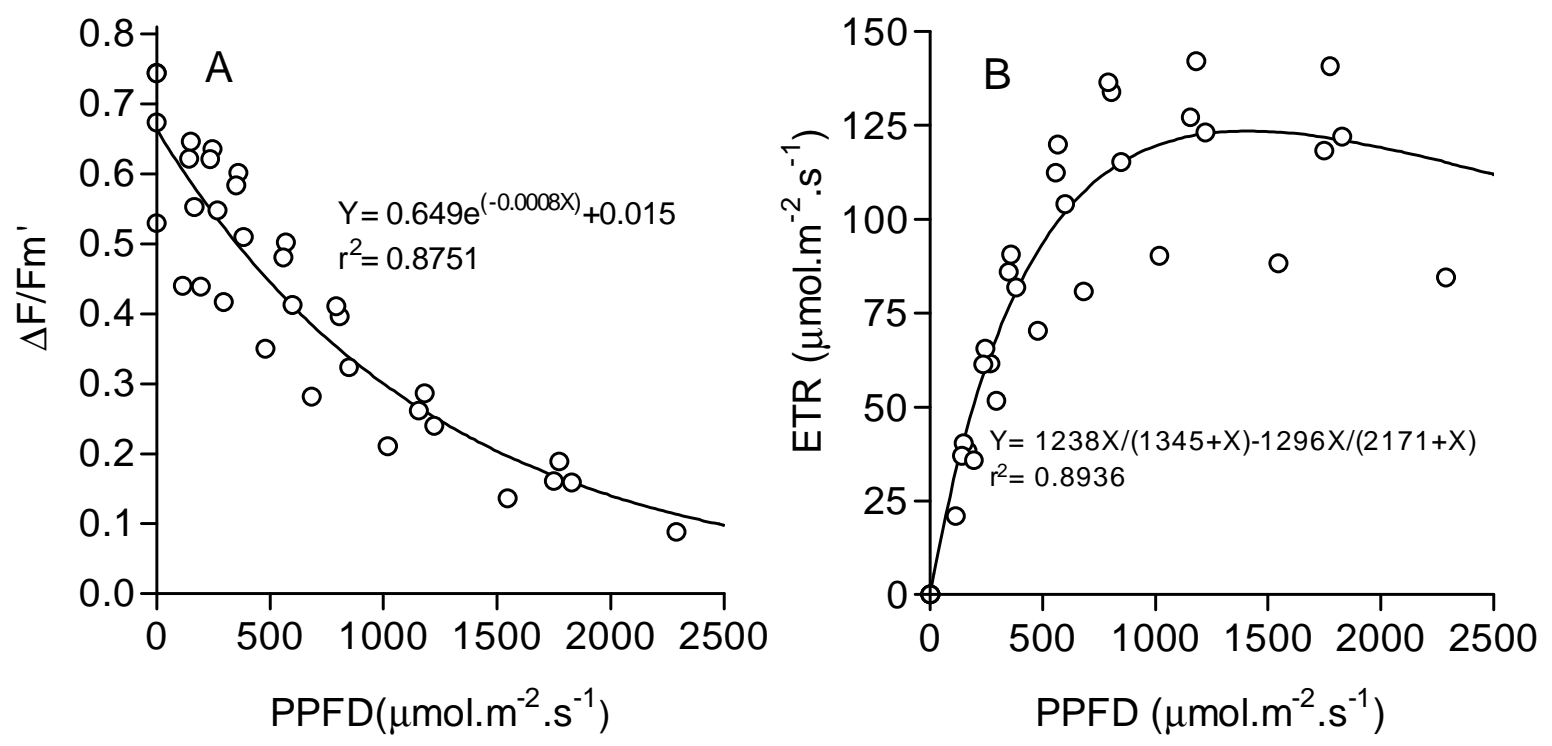

Figure 2. Light response curve of effective quantum yield ( $\Delta \mathrm{F} / \mathrm{Fm}$ ') $(\mathrm{A})$ and apparent electron transport rate (ETR) (B) measured on sun-adapted S. macrophylla leaves.
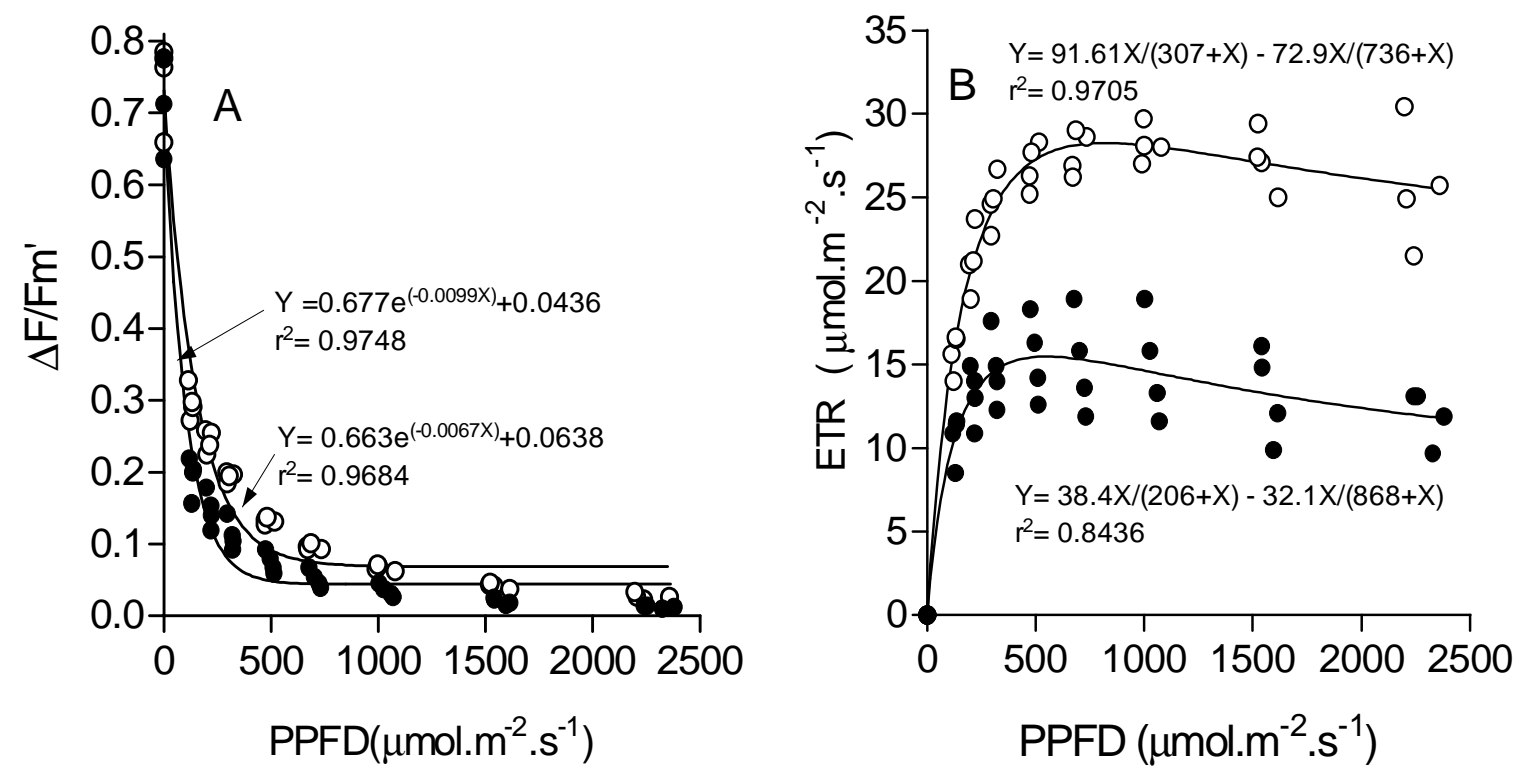

Figure 3. Light response curve of effective quantum yield ( $\left.\Delta / \mathrm{Fm}^{\prime}\right)(\mathrm{A})$ and apparent electron transport rate (ETR) (B) measured on shade-adapted S. macrophylla leaves with (closed symbols) or without (open symbols) sooty mold. 
Light transmitted through the leaf blade increased significantly when the sooty mold was removed from mahogany leaflets (Figure 4). Under an incident photosynthetic photon flux density (PPFD) of $800 \mu \mathrm{mol} . \mathrm{m}^{-2} \mathrm{~s}^{-1}$, the transmitted light increased from $30.4 \pm 4.7$ to $51.3 \pm 4.7 \mu \mathrm{mol} . \mathrm{m}^{-2} \mathrm{~s}^{-1}$, and under $1.600 \mu \mathrm{mol} . \mathrm{m}^{-2} \mathrm{~s}^{-1}$, it increased from $59.5 \pm 1.7$ to 106.4 $\pm 16.6 \mu \mathrm{mol} . \mathrm{m}^{-2} \mathrm{~s}^{-1}$.

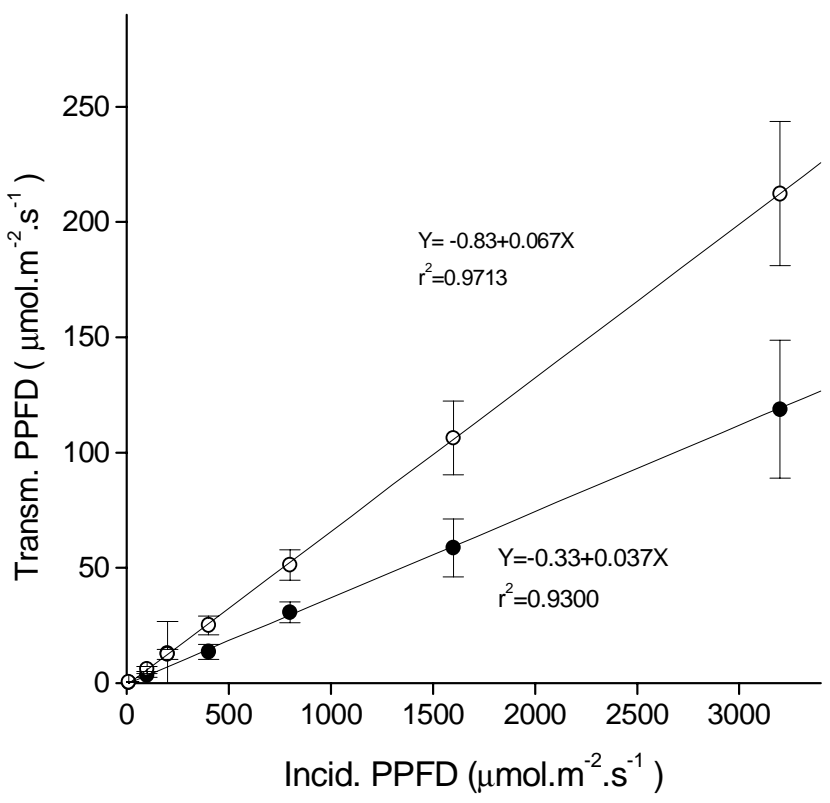

Figure 4. Incident and transmitted photosynthetic photon flux density (PPFD) on S. macrophylla leaves with (closed symbols) or without (open symbols) sooty mold.

The sooty mold on mahogany leaf surface promoted a light blockage of more than $40 \%$, which was in agreement with the data presented by several authors (Gusman e Hart, 1974; Tedders e Smith, 1976, Wood et al., 1988). An evaluation of different levels of sooty mold on the light transmission on pecan leaves (WOOD et al., 1988) showed that a medium mold level reduced at about $24 \%$ the PPFD-transmission, while heavy and extra heavy levels reduced $76 \%$ and 98\% of transmitted PPFD respectively. The authors reported that these reductions were essentially similar at wavelengths between 400 and $700 \mathrm{~nm}$, and so sooty mold density deposition appeared to be acting like a neutral filter.

The photochemical activity is dependent on the light absorbed by leaves and this aspect should be considered in the evaluation of the apparent electron transport rate (ETR). The measurement of light absorption by leaves is possible using an integrating sphere, but is generally not practical to measure (MAXWEll e JoHnSON, 2000). In the present study, the absorption of $84 \%$ of the incident light was used for the computation of the ETR, considering no significant changes on the leaf light reflectance due the sooty mold presence. The data show on figure 4 permit us infer that the most significant effect of fungi mycelium was the blockage of the incident light, thus reducing the absorbed light. As a consequence, the recorded values of the PPFD in the light curves (Figure 3) do not represent the real values of the incident light due the presence of the sooty mold, and thus, the ETR values would be reevaluated considering a decrease of approximately $40 \%$ of the effective incident light. Thus, the initial maximum values of ETR of 15.5 $\mu \mathrm{mol} . \mathrm{m}^{-2} \mathrm{~s}^{-1}$ decreases significantly to $9.3 \mu \mathrm{mol} . \mathrm{m}^{-2} \mathrm{~s}^{-}$ ${ }^{1}$ showing the deleterious effects of the sooty mold presence.

The efficiency of the photosystem II photochemistry of sun leaves of $S$. macrophylla trees was higher than those of shade leaves, independently of the presence of the sooty mold. However the light level for saturating the ETR values for sun mahogany leaves were lower in relation to the observed for three typical cerrado species by Lemos FiLho (2000), which showed ETR saturation at about 1.500 mol.m ${ }^{-2} \mathrm{~s}^{-1}$. This differential response to light was possibly related to the natural distinct environment of the studied species - Cerrado and Amazonian rainforest. In Cerrado, the canopy is typically discontinuous, and the low leaf area index (LAI) values, around 1 in the wet season (Miranda et al., 1997), allow high understory light availability. On the other hand, in the natural environment of $S$. macrophylla, the Amazonian rainforest, the canopy is dense with LAI varying from 5.2 to 7.5 (McWilliam et al., 1993), which results in low light availability below the forest canopy. However, light saturation values of mahogany shade leaves, measured in this study, were similar to those described by BJÖRKMAN e Demmig-Adams (1995) for Oxalis oregana grown under deep shade.

The significant difference between shade and sun leaves of mahogany in relation to light saturation of ETR suggests an adaptation capacity to survive under differential light regimes. According to BRIEZA JUNIOR e SÁ (1994), S. macrophylla is a heliophyte species that can tolerate moderate light levels and whose seedlings can survive under tree canopies, exhibiting low growth rates. This shade adaptation capacity probably results from a low light saturation point, as demonstrated by Lemos Filho e Duarte (1998) for mahogany seedlings grown under deep shade conditions. 
Our data showed that sooty mold presence substantially reduced the values of the maximum electron transport rate (ETRmax), and this reduction corresponded to lower values of the $\left(\Delta \mathrm{F} / \mathrm{Fm} \mathrm{m}^{\prime}\right)$. Due to the reduction of light absorption by the fungal mycelium on the adaxial leaf surface, an additional decrease of ETR values would be expected. WOOD et al (1988) also described a deleterious effect of medium and heavy sooty mold covering on pecan leaves on net photosynthesis ranging from $21 \%$ to $64 \%$ and from $37 \%$ to $69 \%$, respectively.

The sooty mold presence in $S$. macrophylla did not directly damage the leaflets, but the negative effects of sooty mold appeared to be derived from leaf shading, thereby reducing leaf photosynthetic capacity. As S. macrophylla is a species whose seedlings survive under forest canopy, the reduction of photochemical capacity by sooty mold can cause damage to the initial growth.

\section{CONCLUSIONS}

1. Sooty mold presence did not affect leaf structure of S. macrophylla.

2. The photochemical performance of sun leaves of S. macrophylla trees, indicated by chlorophyll fluorescence parameters was higher than that observed on shade leaves.

3. Sooty mold presence on S. macrophylla leaves constitutes a barrier to the light incidence on mesophyll and consequently, reduces the photochemical activity.

\section{ACKNOWLEDGEMENTS}

We are grateful to Dr. David Bird for helping with the English version of the manuscript and to Dra. Rosy Mary S. Isaias for critical reading.

\section{REFERENCES}

BARBOSA, M.R.V. Swietenia macrophylla King. (Meliaceae). In: MELLO-FILHO, L.E.; SOMNER, G.V.; PEIXOTO, A.L. (Coord.). Centuria plantarum brasiliensium exstintionis minitata. São Paulo: Sociedade Botânica do Brasil, 1992. p.167.

BJÖRKMAN, O.; DEMMING-ADAMS, B. Regulation of photosynthetic light energy capture, convertion and dissipation in leaves of higher plants. In: SCHULZE, E.D.; CALDWELL, C.W. (Ed.). Ecology of Photosynthesis. Berlin: Springer-Verlag, 1995. p.17-47.
BRIEZA JUNIOR, S.; SÁ, T.D.A. Sistemas agroflorestais na Amazônia brasileira: espécies arbóreas e atributos desejáveis, In: MONTOYA, L.J.; MEDRADO, M.M.S. (Ed.). CONGRESSO BRASILEIRO SOBRE SISTEMAS AGroflorestais, 1., 1994, Porto Velho. Anais... EMBRAPA-CNPF, 1994. p. 357-373.

BUKATSCH, F. Bemerkungen zur doppelfärbung astrablausafranin. Mikrokosmos, Stuttgart, v.61, p. 255, 1972.

CUTTER, E.G. Plant anatomy: cells and tissues. Part I. London: Willian Clowes and sons, 1978, 315 p.

GERHARDT, K.; FREDRIKSSON, D. Biomass allocation by broad-leaf mahogany seedlings, Swietenia macrophylla (king.), in abandoned pasture and secondary dry forest in Granacaste, Costa Rica. Biotropica, Lawrence, v.27, p.174-182, 1995.

GUSMAN, H.W.;HART, W.G. Reflectance of sooty mold fungus on citrus leaves over the 2.5 to 40 -micrometer wavelength interval. Journal of Economic Entomology, Lanham, v.67, p.479-480, 1974.

JOHANSEN, D. A. Plant microtechnique. New York: McGrawHill Book, 1940. 523 p.

KRALL, J.P.; EDWARDS, G.E. Relationship between photosystem II activity and $\mathrm{CO}_{2}$ Fixation in leaves. Physiologia Plantarum, Lund, v.86, p.180-187, 1992.

LEMOS FILHO, J.P. Fotoinibição de três espécies do cerrado (Annona crassifolia, Eugenia dysenterica e Campomanesia adamantium) na estação seca e na chuva. Revista Brasileira de Botânica, São Paulo, v.23, p. 45-50, 2000.

LEMOS FILHO, J.P.; DUARTE, R.J. Seed reserves partition and light compensation point of Mahogany (Swietenia macrophylla King.) seedlings growth under low photosynthetic active radiation. Brazilian Archives of Biology and Technology, Curitiba, v.41, p.207-211, 1998.

LÜTTGE, U.; HARIDASAN, M.; FERNANDES, G.W.; MATTOS, E.A.; TRIMBORN, P.; FRANCO, A.C.; CALDAS, L.; ZIEGLER, $\mathrm{H}$. Photosynthesis of mistletoes in relation to their hosts at various sites in tropical Brazil. Trees - Structure and Function, Berlin, v.12, p.167-174, 1998.

MAXWELL, K.; JOHNSON, G.N. chlorophyll fluorescence- a practical guide. Journal of Experimental Botany, Lancaster, v.51, p.659-668, 2000.

McWILLIAM, A.L.C.; ROBERTS, J.M.; CABRAL, O.M.R.; LEITÃO, M.V.B.R.; COSTA, A.C.L.; MAITELLI, G.T.; ZAMPARONI, C.A.G.P. Leaf area index and aboveground biomass of terra firme rain forest and adjacent clearings in Amazonia. Functional Ecology, Oxford, v.7, p. 310-317, 1993.

MIRANDA, A.C.; MIRANDA, H.S.; LLOYD, J.; GRACE, J.; FRANCEY, R.J.; MCINTYRE, J.A.; MEIR, P.; TIGGAN, P.; LOCKWOOD, R.; BRASS, J. Fluxes of carbon, water and energy over Brazilian cerrado: an analysis using eddy covariance and stable isotopes. Plant, Cell and Environment, Oxford, v.20, p.315-328, 1997. 
O'BRIEN, T.P.; FEDER, N.; McCULLY, M.E. Polychromatic staining of plant cell walls by toluidine blue. Protoplasma, Vienna, v.59, p.368-373, 1964.

PAIVA, E.A.S.; ISAIAS, R.M.S.; VALE, F.H.A.; QUEIROZ, C.G.S. The influence of light intensity on anatomical structure and pigment contents of Tradescantia pallida (Rose) Hunt. cv. purpurea Boom (Commelinaceae) leaves. Brazilian Archives of Biology and Technology, Curitiba, v.46, n. 4, p. 617-624, 2003.

PENNINGTON, T.D.;STYLES, B.T.; TAYLOR, D.H.A. Meliaceae. Flora Neotropica, New York, v.28, p.1-470, 1981.

REYNOLDS, D.R. Capnodiaceous sooty mold phylogeny. Canadian Journal of Botany, Otawa, v.76, p. 2125-2130, 1998.

SCHREIBER, U.; BILGER, W.; NEUBAUER, C. Chlorophyll fluorescence as a nonintrusive indicator for rapid assessment in vivo photosynthesis. In: SCHULZE, E.D.; CALDWELL, C.W. (Eds.). Ecology of Photosynthesis. Berlin: Springer-Verlag, 1995. p. 49-70.
SPARKS, D.; YATES, I.E. Pecan cultivar susceptibility to sooty mold related to leaf surface morphology. Journal of the American Society for Horticultural Science, Alexandria, v.116, p.6-9, 1991.

STRAUSS-DEBENEDETTI, S.; BERLYN, G.P. Leaf anatomical responses to light in five tropical Moraceae of different successional status. American Journal of Botany, Columbus, v.81, n.12, p.1582-1591, 1994.

TEDDERS, W.L.; SMITH, J.S. Shading effect on Pecan by sooty mold growth. Journal of Economic Entomology, Lanham, v.69, p.551-553, 1976.

VOGELMANN, T.C.; MARTIN, G. The functional significance of palisade tissue: penetration of directional versus diffuse light. Plant Cell and Environment, Oxford, v.16, p.65-72, 1993.

WOOD, B.W.; TEDDERS, W.L.; REILLY, C. C. Sooty mold fungus on pecan foliage suppresses light penetration and net photosynthesis. HortScience, Alexandria, v.23, p.851-853, 1988. 